\title{
D(2) Dopamine Receptor
}

National Cancer Institute

\section{Source}

National Cancer Institute. D(2) Dopamine Receptor. NCI Thesaurus. Code C17292.

$D$ (2) dopamine receptor (443 aa, $\sim 51 \mathrm{kDa}$ ) is encoded by the human DRD2 gene. This protein plays a role in dopamine binding, angiogenesis inhibition, and receptor signaling. 